Studia Judaica 22 (2019), nr 1 (43), s. 49-79

doi:10.4467/24500100STJ.19.004.11231

Aviv Livnat

\title{
Copper and Its Meanderings: Perspectives on Jewish Metaloplastics in a Polish Context
}

\begin{abstract}
Historic copper repoussé was advanced and rejuvenated by the work of Jewish artists in Poland in the period between the two world wars. Numerous metaloplastics exhibitions were held in Warsaw and Łódź, engendering interest in artistic circles and among critics. Through works from the Jewish metaloplastic art scene, copper reliefs by Marek Szwarc, Chaim Hanft, Józef Śliwniak, and Arieh Merzer, the author attempts to shed new light on these very significant modern expressions of Jewish-Polish interactions created with copper. In the context of Polish culture and the art scene, copper was also making its comment on the fragile and complicated contacts between Poles and Jews with its inner spiritual essence of unity and within its depths.
\end{abstract}

Keywords: copper, metaloplastics, Jewish art, Polish-Jewish relations, Judaica.

Słowa kluczowe: miedź, metaloplastyka, sztuka żydowska, relacje polsko-żydowskie, judaika.

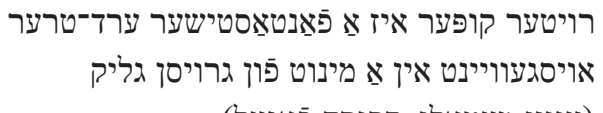

(צוויי מעטאלן, דבורה פַאָגעל)

Red copper is a fantastic earth-tear crying in a moment of great bliss

(Dvoyre Fogel, Two Metals)

The revival of copper in the modern Polish art scene, a trend which gained force during the 1920 s and 1930 s, is a subject that in recent years has 
acquired new focus in modern Jewish-Polish art scholarship. ${ }^{1}$ This artistic expression in the Jewish field reflected social and cultural processes both in the Jewish and Polish spheres and generally in wider art worlds. It arose against the background of the retour à l'ordre of the 1920s and the ongoing spatial investigations of the different avant-garde trends.

Although copper has usually been perceived as a Jewish material, and metaloplastics (copper embossing or hammering) is a technique that was mainly used to create traditional Jewish art and Judaica, the Jewish artists in Poland working with copper strove to connect the copper to contemporary trends and zeitgeist. ${ }^{2}$

Through some specific art works from the Jewish metaloplastic art scene, I will try to shed new light on some very significant modern expressions or reflections of the Jewish-Polish cultural dialogue created with copper. Some of the manifestations of a Polish-Jewish coexistence dream or vision, or sometimes reactions against it, arose from this traditional Jewish material. And thereby reflected the intercultural connections and tendencies in a most unique way as these arose in the metaloplastic Jewish artistic milieu during the 1920s.

I will try to point to a kind of internal shift within a significant Jewish artistic medium of expression from a Jewish perspective of traditional themes and issues connected to the Jewish shtetl, synagogue, and Jewish traditions and customs toward the Polish cultural and social scene. It is a subtle "voice" which was hidden behind the façade of tradition with which the art of copper hammering was usually associated.

\section{Copper as a symbol of Polish-Jewish coexistence}

Indeed, there was a significant shift toward tradition and national expressions during the 1920s, but the metaloplastic artists kept simultaneously trying to express a direct link to Polish spheres, a link they were trying to establish through copper. So copper-a material known for its

${ }^{1}$ Jerzy Malinowski, Malarstwo i rzeźba Żydów polskich w XIX $i$ XX wieku (Warsaw, 2000); Agnieszka Chrzanowska, Metaloplastyka żydowska w Polsce (Warsaw, 2005); Aviv Livnat, "Zikaron rakua be-nekhoshet: Sugiyot be-yetsirato shel ha-aman Arieh Merzer" (Ph.D. dissertation, Tel Aviv University, Tel Aviv, 2011); id., "Arieh Merzer and the Warsaw's Interwar Metaloplastics Art Scene," in Jerzy Malinowski, Renata Piątkowska, Tamara Sztyma-Knasiecka (eds.), Jewish Artists and Central-Eastern Europe: Art Centers, Identity, Heritage from the 19th Century to the Second World War (Warsaw, 2010), 345-351.

2 Livnat, "Zikaron rakua be-nekhoshet," 85-107. 
flexibility—was meandering in Jewish-Polish soil, sometimes revealing hidden layers of a fragile Jewish-Polish social and cultural coexistence.

Copper, symbolically, implies unity, commemoration, and immortalization. In alchemy, it represented the ability to change and bring opposites to unity and this can be seen as a symbol of the vision of true coexistence. How to unify opposites and overcome polar tensions without blurring or confusing their core identities so that they both retain the opposing qualities together with the possibility of merging around a theme, a cause and more. ${ }^{3}$ These were considered to be special spiritual qualities of copper that created its demand for ritual and religious contexts. In this article, I am also trying to examine those qualities in the Polish Jewish social scene, and hence the copper, besides its traditional qualities, can be grasped as a material that symbolically deals and copes with significant tensions and possible reunification or identification.

The copper works made by Jewish artists in Poland, capturing intercultural Jewish-Polish perspectives, were not always acknowledged as such. Because of their rarity, people were often not aware of them. A large corpus of those artworks did not survive the war and some important pieces are known only through their appearance in newspapers and books. Frequently, there was a lack of focus on those artworks from the perspective of Jewish-Polish interactions since they depicted Jewish traditional topics embossed in copper, which was indeed perceived as a traditional Jewish material.

\section{Religious and ritual contexts}

In the Jewish context, the ancient art of copper repoussé is associated with the Biblical figures of Bezalel son of Uri and Oholiab son of Ahisamach, artisans and architects of the Tabernacle (Mishkan) in which they built the Ark of the Covenant and the copper altar. It is said that Bezalel was filled with the Spirit of God, with wisdom, with understanding, with knowledge, and with all kinds of skills-especially, "to make artistic designs for work in gold, silver and bronze." 4

This art form persisted throughout Jewish history, as attested by prayer and ritual items used in the synagogue and the Jewish home. Copper was

${ }^{3}$ Ibid., 67-73.

${ }^{4}$ Exodus 31:4. 
an important and significant material for building the Temple in Jerusalem. In its entrance stood two copper columns- "Boaz" and "Yakhin"- and inside one can find the special cistern of "Yam ha-nehoshet" (the "Sea of Copper"), all created by the Jewish metal artist Hiram alongside copper reliefs and series of copper vessels for the religious practices that took place in the Temple. ${ }^{5}$ Copper played an essential role and the Zohar elaborates on its spiritual merits derived from its ability to cover and protect the Holy. ${ }^{6}$ It is worth mentioning "Nehushtan," the copper serpent Moses had installed following God's command to prevent more killing among the Jews. ${ }^{7}$ The copper serpent was standing in the Temple and was known for its psychological and supernatural healing properties. The art of metal crafting had a special place in ancient Jewish culture and was kept and taught from father to son in the diasporic Jewish communities, especially in Spain, where they created a significant center in which some of the metal artisans, such as Ben Atar, were known as important scholars. ${ }^{8}$

After the expulsion from Spain, Jewish migration to eastern lands also brought this knowledge to Poland and one of the centers of metal carving and crafting was established in Kraków. ${ }^{9}$ In the Polish lands, the art of metal has a long tradition that goes back to the days of Mieszko III the Old. The Jewish metal artists were in charge of producing silver coins and designing metal artifacts and were involved in the production of metal weapons as well..$^{10}$

In the Jewish sphere, metals occupied a significant place in the ritual and religious contexts. The emphasis was always on objects that were located inside the Jewish home and the synagogue: the Holy Ark designs of metal and wood carvings, the Torah scroll with all its metal decorations and plates that combined techniques of chiseling, carving, and hand-hammering. Those were the surroundings where traditional Jewish metal work kept developing and preserving old Jewish symbolism and its iconoclastic tension blended together with local European influences.

51 Kings 7:13-14. See: Shalom Dov Steinberg, Tavnit ha-mishkan ve-keylav uvigdey hakodesh (Jerusalem, 1994), 94-150.

${ }^{6}$ Zohar, Baal ha-Sulam, Pekudey, 229, 71.

${ }^{7}$ Numbers 21:8. The serpent was broken into pieces by Hezekiah at the beginning of his reign (2 Kings, 18:4).

8 Avraham Zoref, Moreshet ha-zorfut be-am Israel (Tel Aviv, 1983), 16.

${ }^{9}$ Ibid.

${ }^{10}$ Moshe Boné, "Hebrew Inscriptions on Medieval Polish Coins," The Shekel 23 (1990), 2:28-37. 
In the Jewish homes at the turn of the twentieth century one could find copper and silver traditional and ritual items such as candlesticks for Shabbat, Chanukah lamps, bowls and Passover plates, goblets and Kiddush cups, spice boxes for Havdalah, the mezuzah, and other ritual items for daily practices and holy days. Those sets of items have evolved over the years and following simple traditional formats, items of a high artistic quality appeared. A significant Jewish center for artistic metal work developed during the eighteenth and nineteenth centuries in Eastern Europe, particularly in Western Ukraine, Galicia, Volhynia and Podolia. The presence of these items in museums and private collections reveals only a fraction of the wealth of these works. ${ }^{11}$ They have been documented in private collections and museums, and their images can be found in catalogues and Jewish art books.

\section{Collections, exhibitions, and literature}

Among the important collections in Poland one can mention the wellknown spices box collection of Mieczysław Zagajski from Gdańsk, ${ }^{12}$ the collection of Maksymilian Goldstein from Lwów (now Lviv), ${ }^{13}$ and Mathias Bersohn's Warsaw collections. ${ }^{14}$

The Dornhelm family from Lwów stood at the center of a modern metaloplastic revival and attracted artists to the city who came to gain expertise and improve their metal artistic abilities. It was their son Baruch who alongside traditional items produced copper reliefs and contributed to the revival of the repoussé technique in Poland at the turn to the twentieth century. ${ }^{15}$

${ }^{11}$ Alexander Kantsedikas, Bronze: Masterpieces of Jewish Art (Moscow, 1991), 9.

${ }^{12}$ Mieczysław Zagajski was a Warsaw industrialist and well-known collector of art and Judaica in Poland.

${ }^{13}$ Maksymiljan Goldstein, Karol Dresdner, Kultura i sztuka ludu żydowskiego na ziemiach polskich (Lwów, 1935). The Goldstein collection stood at the core of the Jewish department of the Lwów ethnographic museum.

14 Zuzanna Rabska, "Bersohn Mathias," in Polski Stownik Biograficzny (Kraków, 1935), 1:469-470; Jacob Shatzky, Geshikhte fun Yidn in Varshe (New York, 1953), 3:328-332. His Judaica collection was the foundation of the Muzeum Starożytności Żydowskich im. Mathiasa Bersohna (Mathias Bersohn Museum of Jewish Antiquities), which was established by the Warsaw Jewish community in 1904.

15 Józef Sandel, Plastishe kunst bay poylishe Yidn (Warsaw, 1964), 164. On Lwów’s metalsmith art scene, see also: Władysław Łoziński, Złotnictwo lwowskie w dawnych wiekach, 1384-1640 (Lwów, 1889). 
The historic copper repoussé was advanced and rejuvenated by the work of Jewish artists in Poland in the period between the two world wars. Numerous metaloplastics exhibitions were held in Warsaw and Łódź during the 1920s and 1930s. Supported often by the Jewish Society for the Encouragement of Fine Arts (Żydowskie Towarzystwo Krzewienia Sztuk Pięknych), they engendered interest in artistic circles and among critics. This group of artists, which included, among others, Marek Szwarc, Yitskhok Brauner, Chaim Hanft, Józef Śliwniak, Johachim Kahane, Henryk Szpigiel, Arieh Merzer, Henryk Chajmowicz, and Hartske Goldshlak, consisted of individual artists who all shared copper as a common platform.

In his books and essays written in Yiddish, Józef Sandel, a Polish-Jewish art historian and critic, showed an awareness of the copper phenomenon emphasizing its important place in the interwar Jewish art scene. One should mention his short monographs on Marek Szwarc, Chaim Hanft, and Arieh Merzer, beginning with the Dornhelm family from Lwów, where he describes Baruch, one of three brothers in the family, as one of the pioneers of the early modern Jewish art of metal repouseé. All of these artists appeared in his last book Plastishe kunst bay poylishe Yidn (published two years after his death) which reflects his perception of the importance of Jewish metaloplastic art and his effort to put it in a historical context. ${ }^{16}$ In March 1964, an article appeared in Yiddishe Shriftn about the metal work of Jewish artists in Poland authored by Sandel's wife Esther Podhoritzer Sandel, who served as the secretary of the Jewish Society for the Promotion of Fine Arts.

16 Józef Sandel not only laid the foundation of research on Jewish-Polish art but upon his return to Poland after the war he himself was actively taking part in the attempt to rejuvenate Jewish artistic life in the country, which would soon seem an almost impossible task. Very little has been written on Sandel probably in view of the fact that he wrote mainly in Yiddish. He can undoubtedly be described as the father of the historiography of Jewish artists in Poland. He paved the way to wider modern research which took place later through the work of researchers such as Jerzy Malinowski and the new wave of contemporary investigations. See Jerzy Malinowski, Renata Piątkowska, Małgorzata Stolarska-Fronia, Tamara Sztyma (eds.), Art in Jewish Society (Toruń, 2014); Malinowski, Piątkowska, SztymaKnasiecka (eds.), Jewish Artists and Central-Eastern Europe. On Sandel's activity after the Second World War see: Renata Piątkowska, "Jewish Society for the Encouragement of Fine Arts / Di yidishe gezelshaft tsu farshpreytn kunst: An Attempt at the Continuation of Jewish Artistic Life in Postwar Poland, 1946-1949," in Elvira Grözinger, Magdalena Ruta (eds.), Under the Red Banner: Yiddish Culture in the Communist Countries in the Postwar Era (Wiesbaden, 2008), 77-96. 


\section{Avant-garde movement in Poland in the 1920s}

It is significant to ask why modern artistic expression in copper crystallized at this precise time at the beginnings of the 1920s and why it did not gain much focus in Jewish art historiography as a distinct phenomenon. In this article, I am proposing a variety of distinctive reasons for the renewal of Jewish artistic expression in copper in Poland in the 1920s. They range from the influence of the general artistic landscape to general contemporary society, and - of course - the political, cultural, and artistic aspects of the Jewish experience.

Modern and avant-garde trends were a platform for communication and mutual dialogue in Poland and quite frequently served as a common artistic medium for Jews and Poles to engage in those new artistic expressions. This was even stronger in Poland than in other countries against the background of Poland's partitions and the artistic and cultural effects, as well as unique influences which emerged within each geographic region.

At the beginning of the twentieth century, when Marinetti published his manifesto in Paris, Poland was still under partitions. The first buds of modern artistic expression began to sprout in all three parts of its territory. Poznań, which lay under the Prussian rule, saw the emergence of the Bunt (the Revolt), an expressionistic form influenced by German art. ${ }^{17}$ Łódź had a Jewish avant-garde movement whose members were identified with the Yung-yidish group developed when Poland regained its independence. ${ }^{18}$ Warsaw developed a Futurist expression that was followed by the Blok Constructivist group..$^{19}$ In Kraków-part of the Austro-Hungarian Empire-the Formiści (the Formists) movement had begun to emerge even before the outbreak of the Great War; its members subsequently joining forces with the Futurist poets and giving expression to their ideas in art practice and theory. ${ }^{20}$

Futurism, Expressionism, Constructivism and other -isms often served as an artistic and theoretical "meta-glue" that brought artists together and in Poland it also contributed to the collaborations of Jews and Poles. The

17 Jerzy Malinowski, Sztuka i nowa wspólnota: Zrzeszenie Artystów "Bunt” 1917-1922 (Wrocław, 1991).

18 Jerzy Malinowski, Grupa "Jung Idysz" i żydowskie środowisko "Nowej Sztuki” w Polsce 1918-1923 (Warsaw, 1987).

${ }_{19}$ Ryszard Stanisławski (ed), Constructivism in Poland 1923-1936: Blok, Praesens, a.r. (Essen, 1973).

20 Joanna Pollakówna, Formiści (Wrocław, 1972). 
modern trends served as a new ground for action and the "artistic coexistence" was already painted with the "vanguard palette" and stylistically depicted a utopian world which was in a way an island or a third zone. ${ }^{21}$ But the 1920s were not only groundbreaking in the political reality that was shaped after the Great War-art was also moving in some new directions with the weakening of the avant-gardes and the reinforcement of traditional trends.

The two Jewish artists, Marek Szwarc and Yitskhok Brauner, took part in the Jewish avant-garde movement of Yung-yidish and the Jewish expressionistic circle, and were among the first artists who shaped new modes of expression in copper. ${ }^{22}$ The Jewish copper from synagogue surroundings and from traditional Jewish artifacts landed in the hands of modern artists who embarked on a new artistic path. This was against the background of contemporary artistic searches for new spatial expressions, the rise of socialism and its influence on art and material culture, the internal cultural and political battles in the Jewish spheres, in tandem with the rise of antisemitism and the multiple attempts for Jewish self-definition.

One should view copper also against the background of modern spatial search and I refer to modern and avant-garde artistic expression in Eastern European art of the day, which-I believe-influenced metaloplastics' spatial motivation. The "fourth dimension" in artistic dialogue in the early twentieth century, "negative sculpture," as well as motivations and inspirations in the realm of the avant-garde, influenced and promoted expressions of "relief" and the search for new spaces. ${ }^{23}$ The wave of Jewish avant-garde as expressed by various Jewish groups in the Russian and Polish sphere had begun to decline and metaloplastics could be seen as an attempt to continue its channel of investigation by revitalizing the relationship with tradition and copper as a Jewish material. We should point to the Polish Futurist avant-garde return to home as expressed in Bruno Jasieński's poem "Futuryzm polski" [Polish Futurism] which describes the 1923 return of the radical avant-gardists to their own dark streets back home. ${ }^{24}$ Influenced by the European retour à l'ordre the Jewish

${ }^{21}$ Marek Bartelik, Early Polish Modern Art: Unity in Multiplicity (Manchester, 2005).

${ }^{22}$ Malinowski, Grupa "Jung Idysz," 15-38, 42-63, 67-71, 75-103.

${ }^{23}$ Livnat, "Zikaron rakua be-nekhoshet"; Linda Dalrymple Henderson, The Fourth Dimension and Non-Euclidean Geometry in Modern Art (Princeton, 1983); Rut Markus, Pisul be-kav uvechalal (Tel Aviv, 2003).

${ }^{24}$ Bruno Jasieński, "Futuryzm polski (bilans)," Zwrotnica, no. 6 (1923); repr. in id., Utwory poetyckie, manifesty, szkice, ed. Edward Balcerzan (Kraków, 1972), 223-239. 
artists who took part in many of the post-war avant-garde platforms were looking for a way to reposition themselves.

It is relevant for our discussion to clearly distinguish the copper work by the Bezalel school from the metaloplastic expression of copper in Poland although there were also direct and indirect links. Jewish artists, such as Lilien, Raban, Schatz, and the Bezalel school, were influenced by the modern expression of the German Jugendstil style from before the Great War or its Austrian manifestation in the Secession movement. ${ }^{25}$ These influences also crystallized with the Polish manifestations of this modern style as expressed in the movement of Młoda Polska (Young Poland) and Sztuka (Art). ${ }^{26}$

The influences wielded by Art Nouveau from the Art and Craft movement with its focus on nature and symbolism together with influences from the Far East and Islam paved another path through which the Bezalel ornamentation could continue and characterize itself in its metaloplastic early works. ${ }^{27}$ Those works had a strong tendency toward ornamental art and it is important to try shed light on two parallel sources for its stylethe traditional Jewish ceremonial and ornamental art and contemporary general decorative art that modern Jewish artists were exposed to.

Direct contact and influences were shaped by artists who were studying and working in the Bezalel school in Jerusalem. The Jewish Polish artist Shimon Kratko was an important exporter of those influences on the Polish Jewish art scene and his modern exotic Jewish style affected many young artists in the Polish art scene..$^{28}$

${ }^{25}$ The influences of the style spread all over Europe and America under different names. In the Russian lands it was called Stil Modern and had influence on Jewish artists in their art and book designs. On influence of the Art-Nouveau artist Beardsley on Lilien see Milly Heyd, "Lilien and Beardsley: 'To the Pure All Things Are Pure'," Journal of Jewish Art 7 (1980), 58-69.

${ }^{26}$ See Jan Cavanaugh, Out Looking in: Early Modern Polish Art, 1890-1918 (Berkeley, 2000).

${ }^{27}$ In the Polish art scene, Stanisław Wyspiański was the important promoter of $A r t$ and Craft with his floral Art Nouveau expression which he combined with traditional Polish elements. See ibid., 97. On John Ruskin's Art and Craft contacts with Poland see Marta Wiszniowska, "Popularity against the Odds: Ruskin and Zakopane," Acta Universitatis Nicolai Copernici: English Studies 5 (1995), 49-57.

${ }^{28}$ On Kratko and his first wife Tea Arciszewska with whom he traveled to Israel and they had together a significant revitalizing influence on the Jewish modern art and culture scene, see Aviv Livnat, "Far undzere kinstler (For Our Artists): Tea Arciszewska and the Jewish Artists," in Malinowski et al. (eds.), Art in Jewish Society, 25-36. 


\section{Cultural, social, and political influences}

Another perspective to be noted regarding the metaloplastic phenomena is through social and political developments. One should examine the connection between copper and societal developments of the time. The social aspect of copper comes to the fore in the proximity of many of these artists to the social ideal-some were even in direct contact with leftist circles. Goldshlak came to copper from the organization of metal workers, and Hanft and Merzer-as I will elaborate later-were active in leftist youth and social platforms and groups ${ }^{29}$ The social ideal is also embodied by the very act of working in copper, which can be seen as "liberating" the Jewish material from the home and the synagogue, from the Orthodox environment to the streets of the world of modern art.

Among the conflicting political-cultural trends, metaloplastics seems to have been an intermediate phase that manifested the need to create middle paths both in the political and the artistic realms - paths of renewed Jewish identity in modern Jewish life, which underwent upheavals due to the magnitude of transformations and changes. A modern Jewish expression was shaped after the Great War and promoted a kind of fusion of Jewish and Futurist, Expressionist and Cubist elements, as expressed in the Second Polish Republic in Yung-yidish, Albatros, Khaliastre (the Gang), and other Jewish avant-garde projects. ${ }^{30}$ In opposition to them stood more conservative Jewish artists and writers who were not attracted to modernism in its international avant-garde form and were expressing closer and tighter links with Jewish content. In the Polish scene there appeared a bitter rivalry between those two camps-the avant-garde groups and the Jewish conservative tendency that was significantly led by Hillel Zeitlin and his son, the poet, Aron Zeitlin. ${ }^{31}$

I view the metaloplastics project that started in 1922 with the first reliefs of Szwarc as a "middle way." And also as a link to social and artistic modernism but without disconnecting the continuity of the Jewish "golden chain." This artistic and cultural split was reflected in the divided political scene of the time. Throughout the stormy, the political entanglement the Jews found themselves in after Grinbaum's tactics of the "Minority block"

${ }^{29}$ Chaim Aronson, "Hartske Goldshlak," Literarishe Bleter 122 (1926), 580-581.

30 Benjamin Harshav, Manifestim shel modernism (Jerusalem, 2001).

${ }^{31}$ Nathan Cohen, Sefer sofer ve-iton, merkaz ha-tarbut ha-yehudit be-Varsha 1918-1942 (Jerusalem, 2002). 
and the bitter disputes that resulted among Jewish audiences, in the face of rising antisemitism and the ongoing Jewish attempts for self-definition, an old-new expression was reborn with the renaissance of copper.

By examining artistic manifestations and responses toward aspects of "living together" or self-definition and identity processes in the Polish context made with copper, I will begin with the artist Arieh Merzer who is known mostly for his depictions of Jewish traditional life, Jewish customs, and Biblical motifs. ${ }^{32}$ Merzer was born in 1905 in the village of Pomiechówek near Warsaw, he studied with the Polish artist and teacher Adam Rychtarski and later joined the circle of Jewish artists in Warsaw. ${ }^{33}$ During the 1930s he worked in Paris and after the Nazi invasion of France he escaped south and was a refugee and later a camp laborer in Switzerland. ${ }^{34} \mathrm{He}$ immigrated with his family to Israel in 1945, settled in the city of Safed, and was one of the founders of the Artists' Colony where his studio attracted devotees of Jewish art and culture from Israel and around the world. ${ }^{35}$

The relief Carnival is a rare relief in his body of work, depicting a street scene from a carnival (see Fig. 1). This piece did not depict a typical literary or traditional theme and differed from his corpus of social themes as well. During my research I have located several hundred works by Merzer from all over the world. Merzer kept the largest collection of copper reliefs from the Polish metaloplastic circle. I also tried to locate a youth art newspaper Merzer had been editing together with Moshe Grosman, Shmuel L. Shneiderman, and other friends from the youth party of the Left Poalei Zion in Warsaw at the beginning of the 1920s. This was a left wing

32 See Livnat, "Zikaron rakua be-nekhoshet." On his Warsaw period, see id., "Arieh Merzer and the Warsaw's interwar metaloplastics," in Malinowski et al. (eds.), Jewish Artists and Central-Eastern Europe, 345-351. On Merzer among the Montparnass Jewish artists, see Chil Aronson, Bilder un geshtaltn fun Montparnass (Paris, 1963), 586-592. On his Safed period, see Aviv Livnat, "Rikuey ha-nekhoshet shel Arieh Merzer: Zikhronot Yidish miTsfat," Motar 19-20 (2012), 7-22.

${ }_{33}$ Adam Rychtarski was appointed head of the Szkoła Malarstwa i Rysunku im. Konrada Krzyżanowskiego (the Konrad Krzyżanowski School of Painting and Drawing) after the founder's death in 1922. On Rychtarski, see Małgorzata Kurasiak (ed.), Adam Rychtarski 1885-1957: Malarstwo (Łódź, 1981).

${ }^{34}$ Merzer worked in a forced labor camp, Camp de Sierre, and then he moved to Geneva. The series of sketches from his period in the camp are in the collection of the Yad Vashem Museum.

${ }^{35}$ Merzer was active in Safed until his sudden death on the eve of the Holocaust Memorial Day in 1966. For copper reliefs from his Safed period see Arieh Merzer, Safed and Its People: Eighteen Reliefs in Metal (Safed, 1965) and id., Biblical Images: Sixteen Copper Reliefs, intro. Itzik Manger (Safed, 1959). 


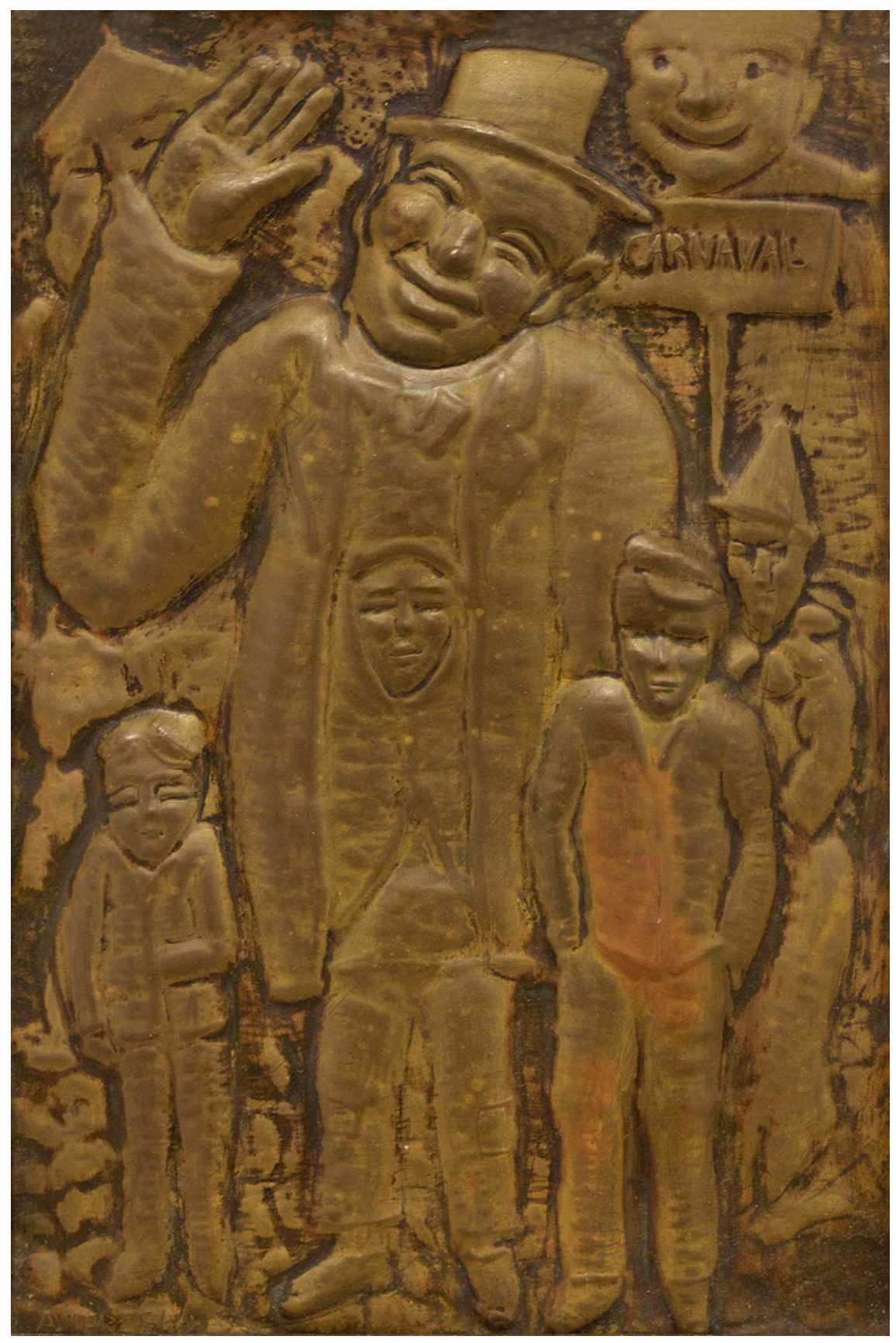

Fig. 1. Arieh Merzer, Carnival, copper relief, the early 1930s, The Merzer Archive Collection, Tel Aviv [henceforth: MAC]. 
avant-garde youth journal influenced by the latest journals of Yung-yidish, Khaliastre, Albatros, and especially by the early expressionistic literature of Uri Zvi Greenberg. It was titled Barg aroyf [Ascending Uphill] and published in several dozen copies editions which were almost impossible to locate in archives and libraries since they did not survive the war. After several years of research, I had the good fortune to finally locate those Yiddish pages in a private attic in Hawaii where I discovered a short literary fragment by the twenty-year-old Merzer entitled "Karnaval," signed "geshribn in a carnival 1923": at the time he was still residing in Warsaw. ${ }^{36}$

The idea of the Polish Christian carnival inspired the mind of the young Merzer, which through its German Nietzschean perspective had found its way into the Yiddish avant-garde circles of poets and artists. It was an expressionistic secular call for a new order away from the traditional and daily Jewish world. Instead of God, Mephistopheles was active and the carnival symbolized or enabled the awareness for a modern new orderwhich was not always optimistic. It was the traditional Polish carnival which echoed internal processes in the Jewish sphere and therefore attracted and inspired artists.

In theory it was Mikhail Bakhtin who imported the idea of the carnival as an event for bringing people together and encouraging the interaction and free expression between them. ${ }^{37}$ It is a celebration in which all rules, inhibitions, restrictions, and regulations which determine the course of everyday life are suspended, especially all forms of hierarchy in society.

Bakhtin offers several categories for what he calls the "carnivalistic" sense of the world. Free and familiar interaction between people takes place during the carnival when people —normally separated — can interact and freely express themselves. Human nature's hidden sides are revealed through sometimes inappropriate eccentric behavior. Bakhtin emphasized the carnival as a zone of connections-bringing together or expressing unity of opposites: night and day, old and young, foreigners and locals, children and adults, etc. The free and familiar attitude of the carnival

${ }^{36}$ After persuading the daughter of Meir Ader, a member of the young group, to look for the third time, she phoned me with the news that a few pages in an unknown language were found. Apparently those were the Yiddish pages of one of the few surviving copies of the lost journal. See Livnat, "Zikaron rakua be-nekhoshet," 161-168.

${ }^{37}$ This concept was brought to literary theory by Bakhtin in his controversial research on Rabelais, which was a radical attempt to merge Russian formalism with the rising Marxist outlook, see Mikhail Bakhtin, Rabelais and His World, trans. Hélène Iswolsky (Bloomington, 1941); Simon Dentith, Bakhtinian Thought: An Introductory Reader (London, 1995), $65-88$. 
enables everything which is normally separated to connect: one can add the sacred with the profane, the new and the old, the high and the low, and more. Another aspect of the carnival for Bakhtin was its perception as a site of ungodliness, of blasphemy, profanity, and parodies of things that are sacred. In the carnivalesque literature and outlook that was promoted by Bakhtin's thought, a new world order was created, which endlessly tested ideas and truths and called for equal dialogic interactions.

Focusing on Merzer's copper relief, we can see several figures of children and what looks like puppets and masks in a mixed setting so that one does not easily recognize who stands on his own feet, and as a result we get a kind of carnivalesque fusion. We can see a central figure surrounded by a group of children. Just behind, stands a young boy with a pointed clown hat holding a placard entitled Carnaval. Behind him is a large clown mask which resembles the grotesque painting of Witold Wojtkiewicz entitled Circus II from 1906-1907 (see Fig. 2). The large figure placed in the center occupying much of the compositional space contributes to the carnivalesque caricature mood. Looking carefully, we see a child's face appearing from the figure's belly. It seems like the child is carrying the figure as a giant puppet or marionette. Its short legs, which do not match the figure's proportions and in fact are more in harmony with the feet of all the other children around the scene, contribute to this effect.

Merzer created this tricky figure which plays on two parallel conventions of perception, the first views the child in the adult and the second vice versa: the adult carried by the child. What are those opposites and how do they interact in this festive happening? I understand this as a visual illustration of what Bakhtin would later try to convey in his carnivalesque reading of literature. This disorientation and ambivalence blurs the oppositions and contributes to the emergence of a new zone of happening which goes beyond traditional social hierarchies. In Merzer's composition, this quality is implied in the core of the figure where the face of the child is peeping and looking around. This is a kind of secret window to the carnival quality which comes from the depth of copper.

But in the composition also the child with his hands in his pockets can be seen-in a kind of indifferent posture gazing at the event. Does he really participate in it? All the "voices" of the "others"- the individuals participating in the festival—express themselves through the figure's big open festive hands which are waving openly, expressing the unique carnival state of mind and emotions. The masks are important festive ingredients 


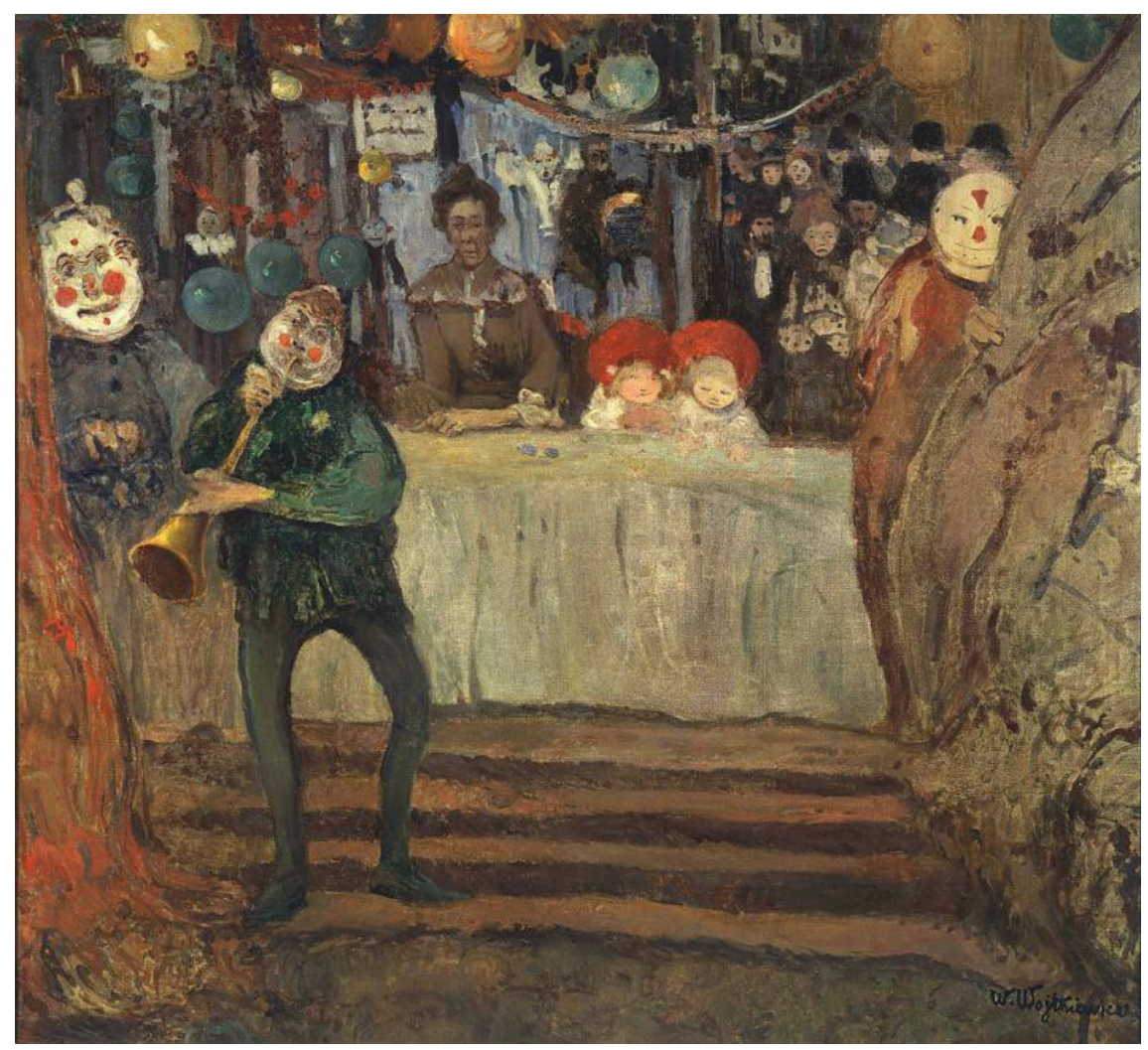

Fig. 2. Witold Wojtkiewicz, Circus II, oil painting, 1906-1907, Muzeum Narodowe, Warszawa.

in the carnival, contributing to the merging of identities, the blurring of the real and imagined, of truth and falsehood. When one holds a mask, he hides himself behind it, but he does not pretend he is not there. In a kind of presence-absence activity, the mask reveals the unidentified poly-identities' world of the carnival. Bakhtin tried to hear this polyphony in Rabelais's text. Merzer, as I attempt to explore in this article, expressed it through his copper embossed in the Polish-Jewish sphere.

It is not the Jewish festival of Purim which could be a natural field of inquiry into the festive quality of joy and freedom to be the target of Merzer's artistic expression. It is rather the Polish carnival which attracted Merzer's creative attention and reflected a special attraction toward traditional Polish customs to which a young Jewish artist could relate to. 
Does he stare from the outside through the festive mask? Or is he a free participant?

I have chosen two other reliefs from the social subjects Merzer developed around the 1930s (see Figs. 3 and 4). If the perspective in Carnival revolves around festivals or holy days which are dates that can possibly serve as zones of encounter, although their ethnic or religious specifics were alien to the Jewish traditional custom, in the following works there appears a solid mutual motif that brought Poles and Jews together. It was under the red banner in multiple variations which all lured the workerwhether a Jew or a Pole-as an equal comrade in the battle for the new social order. There was a great affinity between leftist Jewish and Polish circles not only in the political arena but also in culture and education. It is worth mentioning the khavershaft (friendship) episode in the film Mir kumen on made by Aleksander Ford in the Bundist Medem Sanatorium for children in Miedzeszyn. ${ }^{38}$ The Jewish children of the sanatorium welcomed a visit of Polish kids. These were the children of the mine workers who had set up a strike causing a big political scandal. The Jewish left supported them, and the children in the film reflect this mutual understanding and identification. Unfortunately, the establishment was not very understanding and due to that episode the film was banned in Poland.

Merzer, like several other members of the Jewish metaloplasic artists, was close to leftist circles and his affinities with leftist ideals were reflected in his art, as well as in his social and educational activities. Upon arriving in Paris, Merzer attracted the attention of art critics with his social copper reliefs which gave a twist to the traditional Jewish thematics of copper.

In the first relief Merzer depicts a scene of a gathering in front of the Pawiak - the infamous prison at Pawia Street in Warsaw (see Fig. 3). A speaker is carried by several people, raises his hands up in the air, and preaches to a large audience which gathers around. In 1905, there were some dramatic events in that specific location. Between 27 January and 1 October hundreds of citizens died, among them many Jews. ${ }^{39}$ After the death of Israel Gravir, a tailor, a gathering of 30 thousand Jewish

${ }^{38}$ See Mir kumen on [Here We Come, American title: Children Must Laugh] (Poland, 1935), 63 minutes, B\&W, English and Yiddish with English subtitles, directed by Aleksander Ford for the Jewish Labor Bund.

39 The newspaper mentions 93 casualties only in Warsaw, see Ha-Tzefirah (13 Feb. 1905). See Scott Ury, Barricades and Banners: The Revolution of 1905 and the Transformation of Warsaw Jewry (Stanford, 2012). 


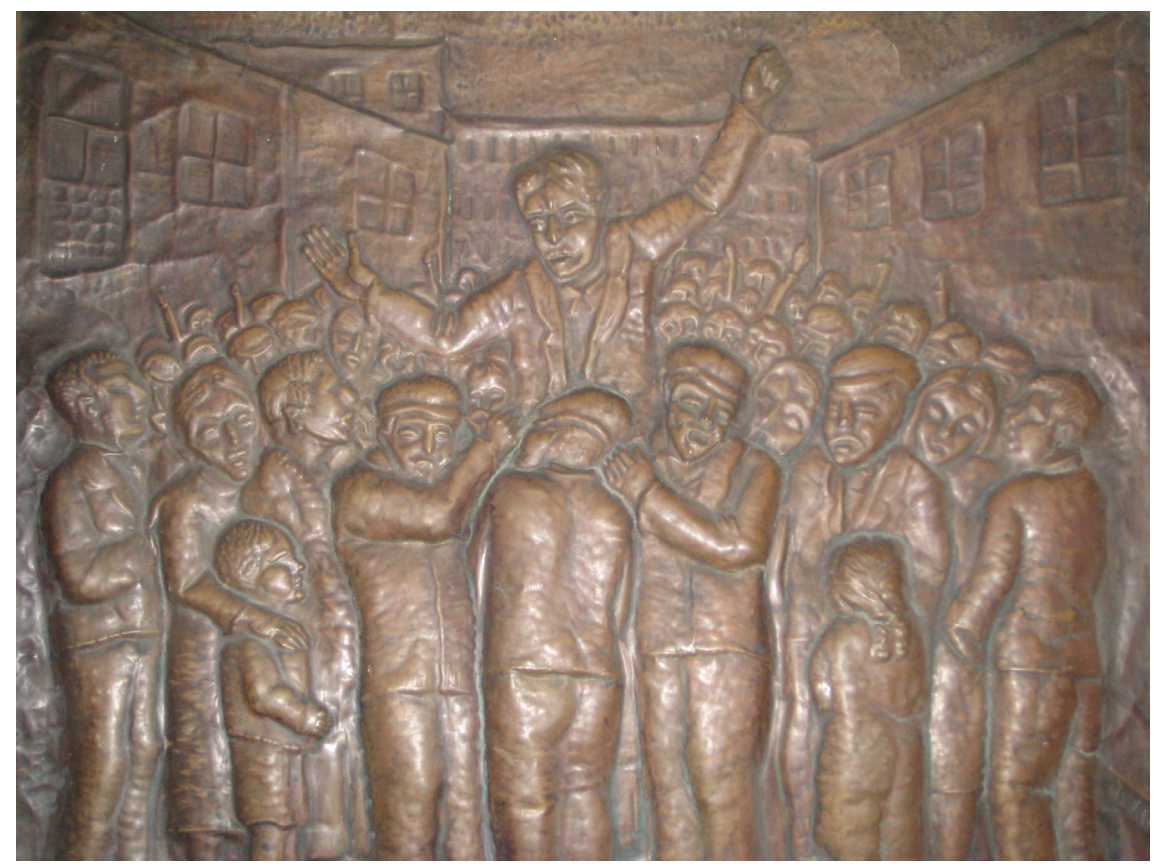

Fig. 3. Arieh Merzer, Demonstration, copper relief, 1930, MAC.

workers faced a violent reaction and again there were many casualties. ${ }^{40}$ Those were mythological days in the history and collective memory of the struggle of the working class in Poland and although different parties and organizations both Jewish and Polish were active with different emphasis and agendas, there was a clear common cause that provided the mutual framework of action.

The next scene depicts the social awakening or rebellion inside a factory (see Fig. 4). The workers are listening to their colleague, the leader who stands on a table, raises up his hands with tightly closed fists, and probably expresses calls for their human and legal rights. He stands in front of the machinery of the factory while three other figures express different reactions to this call through their body language.

The copper not only served as a material for religious and traditional Jewish objects but through the work of the Polish metaloplastic group

${ }^{40}$ Among them Salomon Margolin and Fruma Grabelski who were in the group of speakers, see Yitskhok Grinboim (ed.), Varsha: Encyclopedia shel Galuyot (Jerusalem, 1953-1973), 64-65. 


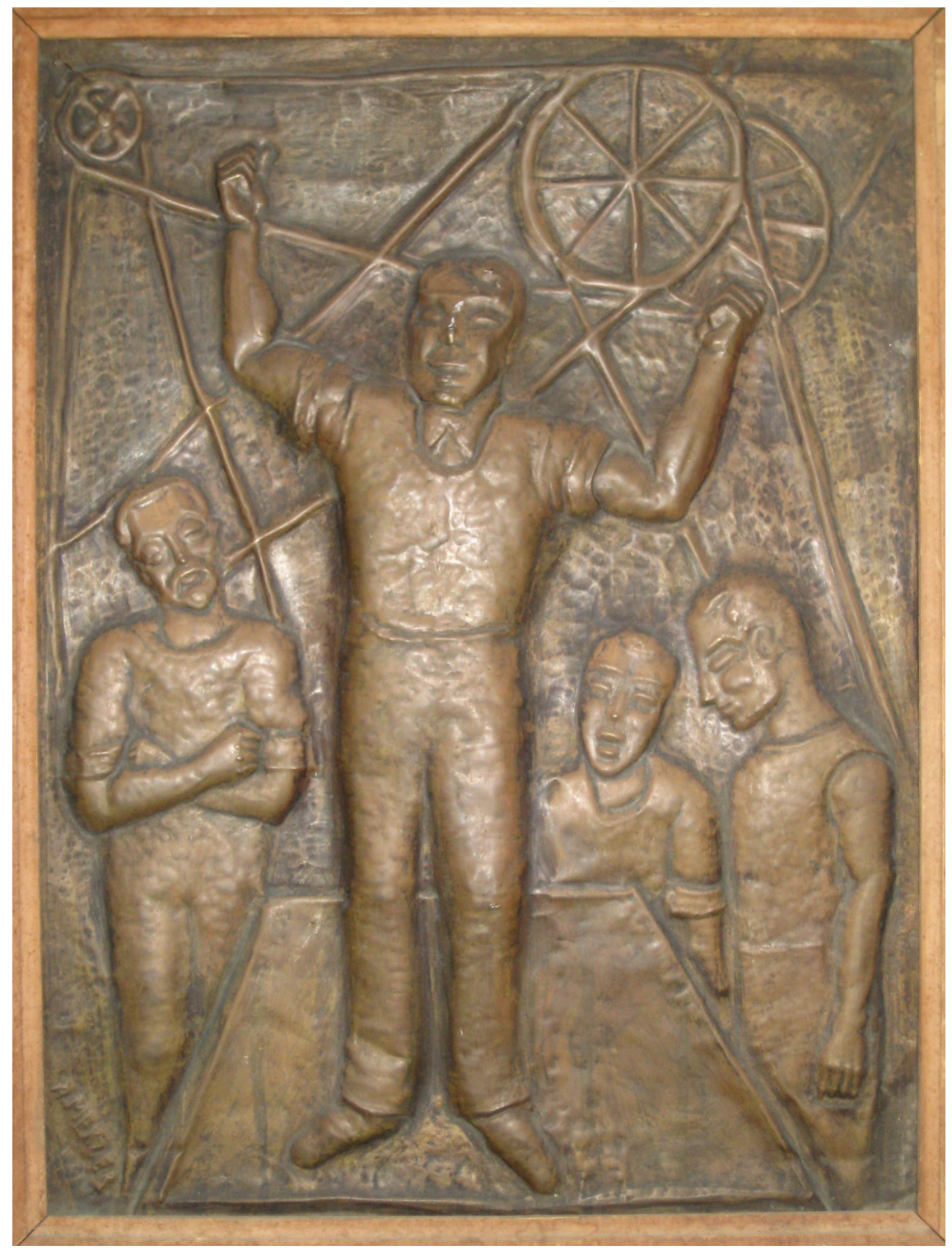

Fig. 4. Arieh Merzer, Protest in the factory, copper relief, 1930, MAC. 
also gained a more contemporary articulation. I am referring here to the work of Chaim Hanft (1901/3-1951) who in his work expressed social subjects and was often involved in leftist projects and activities. ${ }^{41} \mathrm{He}$ was close to the leftist circles in Germany where he was attracted to the Spartakus revolutionary group and later, during the 1930s, took part in the leftist Polish Jewish radical artists group Czapka Frygijska (Phrygian Cap) ${ }^{42} \mathrm{He}$ contributed satirical drawings to the leftist Literarishe Tribuna, a journal of a high artistic standard. Years before, during the Beilis trial in 1913, young Hanft made his debut appearance in the Warsaw journalistic scene with his imaginary drawings on the subject which troubled him as a young Jewish boy. When his father was recruited into the army during the Great War, Hanft had to support the family and again he tried to earn some money by knocking on Polish and Jewish doors and trying to sell his drawings. It was Glicenstein who took him under his patronage and helped him to enter the Warsaw art school and later acquainted him with the already active and established artists, such as Henryk Berlewi, Joseph Zeidenbeutel, and Ber Kratko.

Hanft was a prolific artist working as a sculptor and painter, as well as a copper artist. At the archive of the Jewish Historical Institute (ŻIH) in Warsaw, an important work of documentation includes photos of his copper designs for radiators [Kalorifer]. One was located at Tłomackie 13 and others in bourgeois Jewish and Polish homes, even in the palace of Count Czartoryski (see Fig. 5).

\section{Religious and Biblical inspirations}

Copper was, in some sense, finding its way from a closed traditional Jewish context to a more general open common use, not only by bringing the warmth of the copper material itself, but by connecting it to the physical warmth spread by the radiators. Metaloplastic design contributed to the internal design of both Jewish and Polish surroundings.

${ }^{41}$ Sandel, Plastishe kunst bay poylishe Yidn, 189-180.

${ }^{42}$ Czapka Frygijska was a group of artists from Warsaw who in the years 1934-1938 represented radical social ideas and communist beliefs. Among its Jewish members were Józef Herman, Isaac Perel, H. Szerer, Ichiel Tynowicki, and among its Polish artists were Franciszek Bartoszek, Zygmunt Bobowski, Kazimierz Gede, Franciszek Parecki, Mieczysław Berman. See Malinowski, Malarstwo i rzeźba Żydów polskich, 276. 


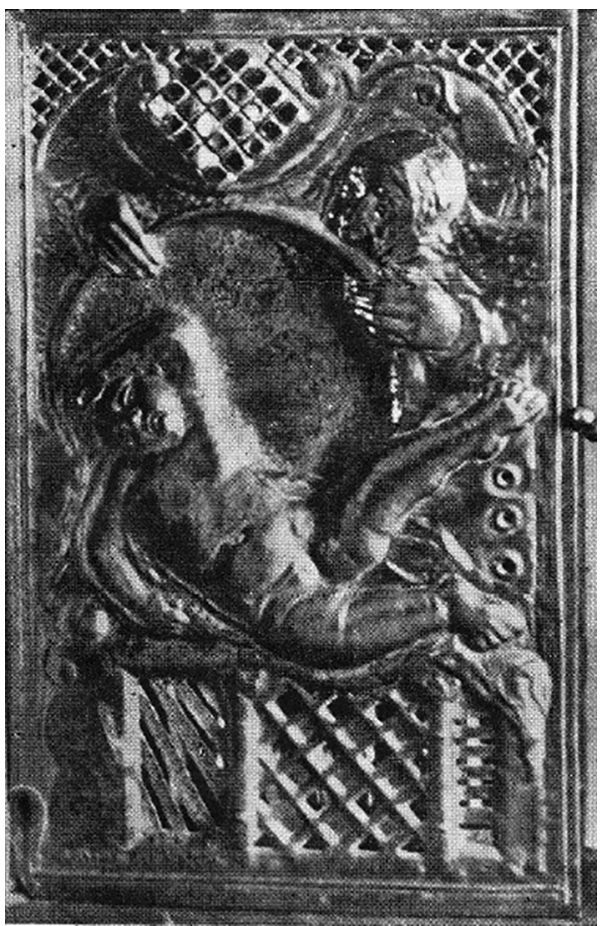

Fig. 5. Chaim Hanft, Copper design for a radiator in the palace of Count Czartoryski, around the 1930s, Yidishe Shriftn 5 (1961), 8.

Marek Szwarc, who was born in Zgierz in 1892, was one of the Yungyidish members and previously took part in the Jewish avant-garde circles in Paris around the Makhmadim project. ${ }^{43}$ During the 1920s he switched to metal hammering and was a main influence in that field. Szwarc was an important voice in the Jewish art scene, a voice which he frequently expressed in his essays and reportages in Jewish Polish art journals of the time. In those years, Szwarc kept close contact with the Poznań Expressionist and Formist Polish artists. His Biblical scenes not only maintained gothic atmosphere and influences but his inner search brought him toward Christianity. Without elaborating this story here, I want to point to the Bible corpus as a possible source or zone of encounter between Jews and Christians. As we know, throughout the history of Western art there is a kind of rival hermeneutics with parallel interpretations of the scriptures both from the Jewish and the Christian perspectives; but could they coexist? The Christian perspectives grasp both narratives, but undoubtedly

${ }^{43}$ Sandel, Plastishe kunst bay poylishe Yidn, 174-180. 
give priority to the second phase of interpretation which shows the Old Testament's narrative as a prefiguration to events or aspects of Christ and his revelation.

Szwarc's Cain and Abel (a relief dated 1930) depicts the Biblical scene of two brothers in battle (see Fig. 6). It is a story of a clash between two brothers where one stood up to and killed the other. Firstly, it reflects the fragility and state of crisis between the brothers or-we might saybetween neighbors in the community of the fragile post-war Polish new political and social reality. But Szwarc, who had already got closer to Christianity, might also be expressing some ideas or concepts from a Christian perspective which sees the act of the killing of Abel as a prefiguration of Jesus's crucifixion. Between the Cain and Abel story and the Jesus crucifixion there are some parallels which are often expressed through art works dealing with the subject. God's acceptance of Abel's sacrifice reminds us of Jesus's sacrifice for the sake of humankind. The attack of the older brother on the younger can be seen as parallel to the "harassment" of the people of the New Testament by the people of the Old Testament. In this

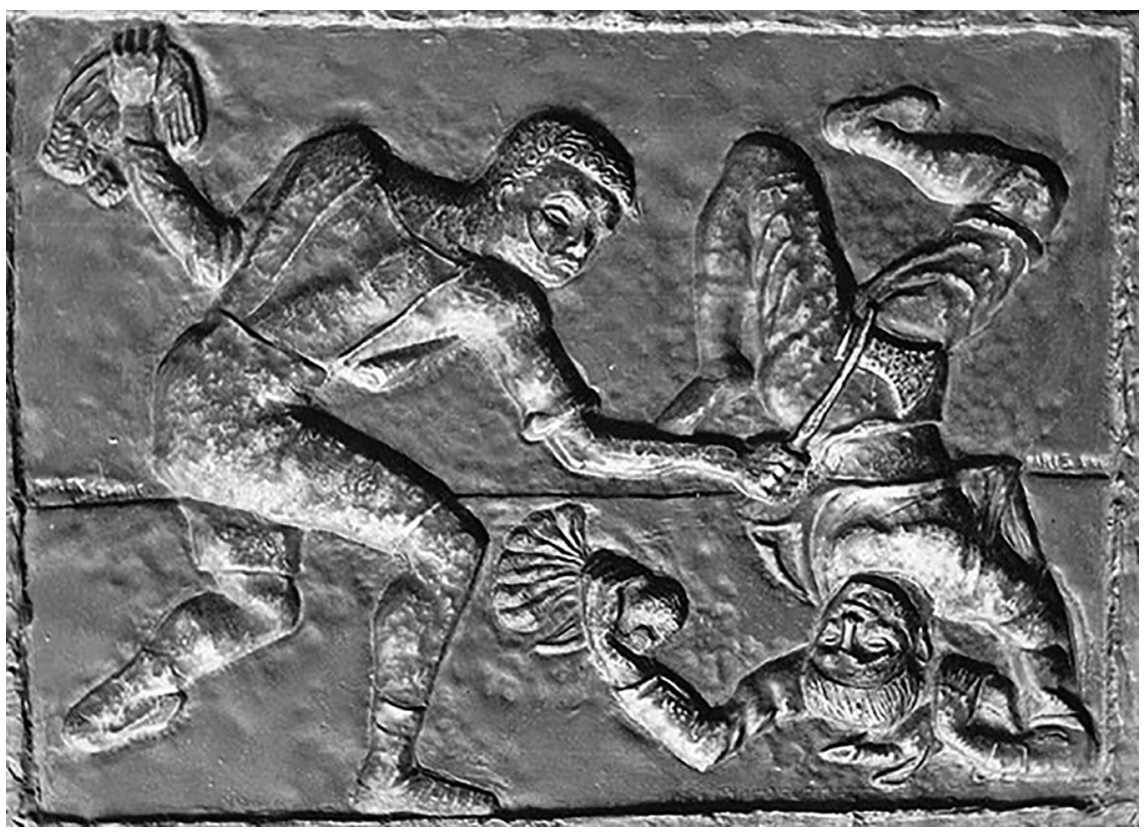

Fig. 6. Marek Szwarc, Cain and Abel, copper relief, 1930, Louis Vauxcelles, Marek Szwarc (Paris 1932). 
perspective Cain's mark is reminiscent of the badges and marks which Jews carried throughout the centuries. But Szwarc continued to identify deeply with Judaism and explored its expressions in contemporary art as can be seen in his writings years after his conversion..$^{44}$ But this sort of coexistence was not acceptable in the Jewish traditional milieu, let alone a religious one. His Jewish Polish family severed all contact with him and his daughter Tereska Torrès, the writer who grew up as a child in Paris entering churches through the back doors together with her father and wrote about this experience which dramatically shaped her life..$^{45}$

Szwarc's conversion shocked the Jewish artistic and cultural milieu, especially due to his high artistic achievements as a Jewish artist from the days of Yung-yidish to his important role as a pioneer of the new Jewish metaloplastic expression. When the news about his conversion spread in the press, the journalist Shneiderman described the direct effect it had on the young artist Arieh Merzer for whom Szwarc was an important model. Even Merzer's later emphasis on Jewish themes as opposed to social and general themes which he exhibited during the 1930s in France can be seen in the context of upholding the banner of Jewish metaloplastics, a task which Merzer as the only survivor from the Polish group had carried with him to Safed. ${ }^{46}$

Merzer continued to concentrate on Biblical scenes, the Jewish shtetl, and a rejuvenated Safed, which are all laid one on top of the other as layers of memory, and are built one from the other within the copper. It is not the memory of the village, but rather the memory of the village within Safed and from within a simultaneous reflection of the Bible. The archaeological layers open for reading in the space of the copper do not find each other as at an archaeological site, which demands that one layer be selected at the expense of another. Rather, they permit a simultaneous reading that recreates the various spaces in the transparency of the copper. ${ }^{47}$

Merzer's Cain and Abel from his Safed period reflects a more harmonious approach in which the brothers are closer, touching each other, and their faces reflect a kind of calm and spiritual expression (see Fig. 7). As opposed to the more gothic-like sharp axe lines of Szwarc's relief, Merzer

${ }^{44}$ See Marek Szwarc, "Der natsyonaler element in der yidisher kunst," Literarishe Bleter 48 (1925), 1-2.

45 Tereska Torrès, The Converts (London, 1970).

${ }^{46}$ Shmuel Leyb Shnayderman, "Arieh Merzer in Tsfat," Yidishe Kemfer (27 May 1966).

${ }^{47}$ On Merzer's copper spatial concepts see Livnat, "Zikaron rakua be-nekhoshet," 268-271, 447-449. 


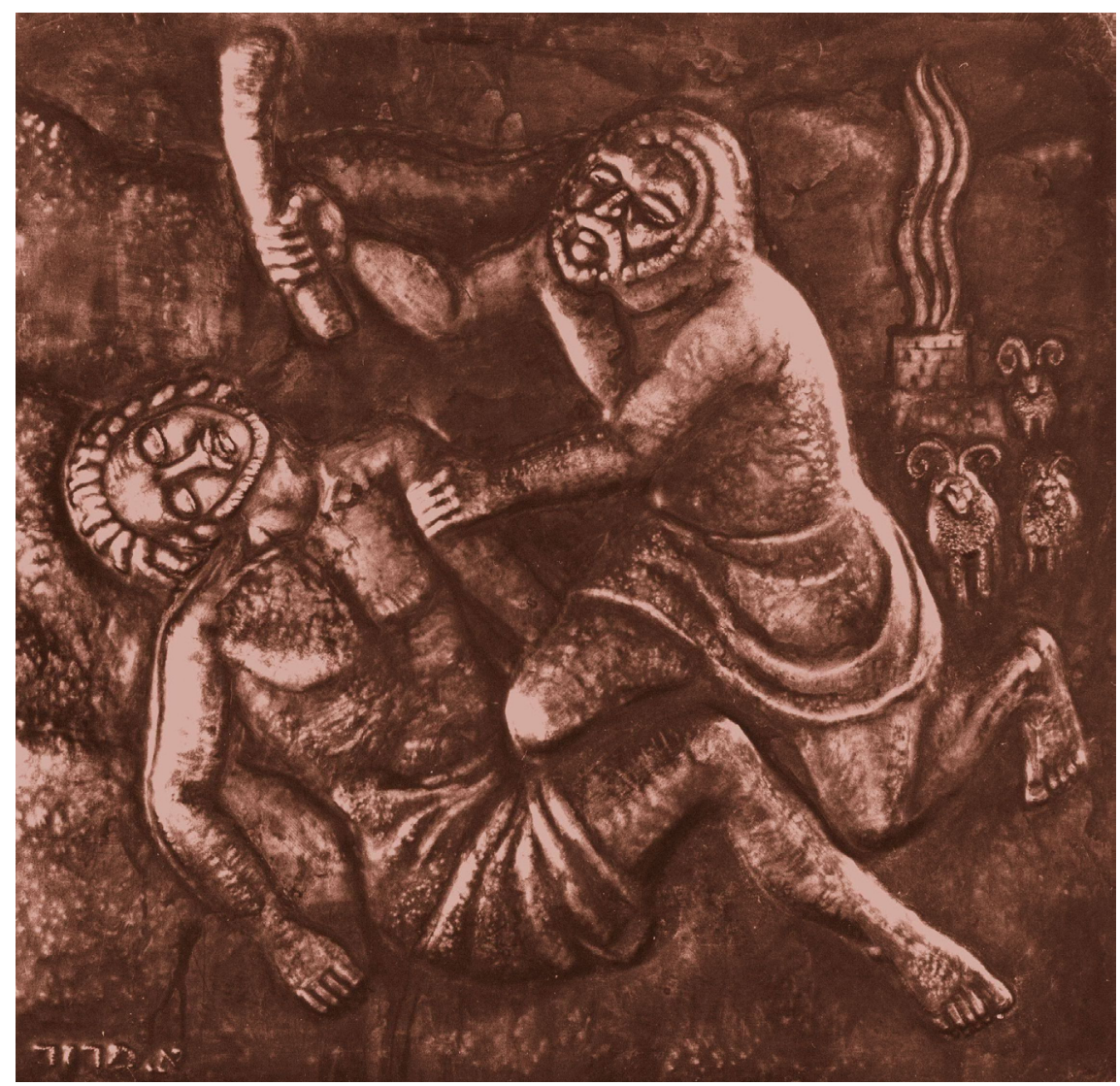

Fig. 7. Arieh Merzer, Cain and Abel, copper relief, 1946, MAC.

created curved and flowing lines that not only divide the brothers in the midst of their quarrel, but connect them as well. This is based on an interpretation of the first brotherly fight and murder in human history as an internal fight between realms in man's own existence. This struggle between belief and enlightenment, earth and heaven is created by Merzer with a kind of circular movement which echoes I. L. Peretz's Cain and Abel who "comes back to life every generation to die again forever." 48

The Bible plays a different role in a well-known work by Józef Śliwniak who was born in Kiev in 1899, grew up in Warsaw, and was murdered in

48 Yitzhok Leibush Peretz, "Kain ve-Hevel," in id., Mayselekh (New York, 1920), 249-254. 
Treblinka in $1942 .{ }^{49} \mathrm{He}$ was a painter and a copper relief artist, and also created designs for the theater, working for the Vilna troupe, Viket (Varshever Yidisher Kunst Teater [Warsaw Yiddish Art Theater]) and Azazel theaters. The ŻIH collection holds two reliefs by the artist, one of these being the subject of my examination. I would like to reflect upon his relief depicting Rahab and the two spies since I discovered a layer that in my view is connected with the Polish-Jewish mutual perspective (see Fig. 8).

According to the Book of Joshua, Rahab was a prostitute living in the city of Jericho and took part in the conquering of the city by the Israelites. ${ }^{50}$ When the Hebrews were encamped at Shittim, in the "Arabah" opposite Jericho, ready to cross the river, Joshua, as a final preparation, sent out two spies to investigate the military strength of Jericho. The spies stayed in Rahab's house, which was built into the city wall. The soldiers sent to capture the spies asked Rahab to bring out the spies. Instead, she protected them by hiding them under bundles of flax on the roof and saved them. After escaping, the spies promised to spare Rahab and her family after the triumph over the city-even if there should be a massacre-if she marked her house by hanging a red cord out of the window. It was an act of cooperation in a deep sense. In Judaism she was not only perceived as a Gentile that joined the Israelites, but later on as an ancestor of saints and prophets. ${ }^{51}$ According to the New Testament her connections to Jesus and King David are shown in a genealogy. ${ }^{52}$

In Hebrew the name Rahab stands for "opened" or "widened." Playing with the order of letters of her name, one gets: "friend, joining together," and "choosing." This copper work from the late 1930s presents the story of collaboration between people from different nations against the background of the fears of war and death, for an important cause and for salvation. In the context of the increasing growing tensions between Poles and Jews during the1930s, I read this work by Śliwniak as a cry for cooperation,

49 Jonas Turkow mentions him marching silently, dressed in a white mantle, among the group of artists that were deported from the Warsaw ghetto during August 1942. See Yonas Turkow, Hayo hayta Varsha ha-yehudit (Tel Aviv, 1969), 148. See Josef Sandel, Umgekumene yidishe kinstler (Warsaw, 1957), 148-150; Malinowski, Malarstwo i rzeźba Żydów polskich, 273-274.

${ }^{50}$ Book of Joshua 2:1-7.

${ }^{51}$ Nir Tibi, "Rahav ha-zona beyn megamot ba-mikra uvamidrash: Sipur bavua midrashi," Moresht Israel 12 (2015), 162-175.

${ }^{52}$ Her name is mentioned in the Gospel of Matthew as one of the ancestors of Jesus (Matthew 1:5). She married Salmon of the tribe of Judah and was the mother of Boaz. 


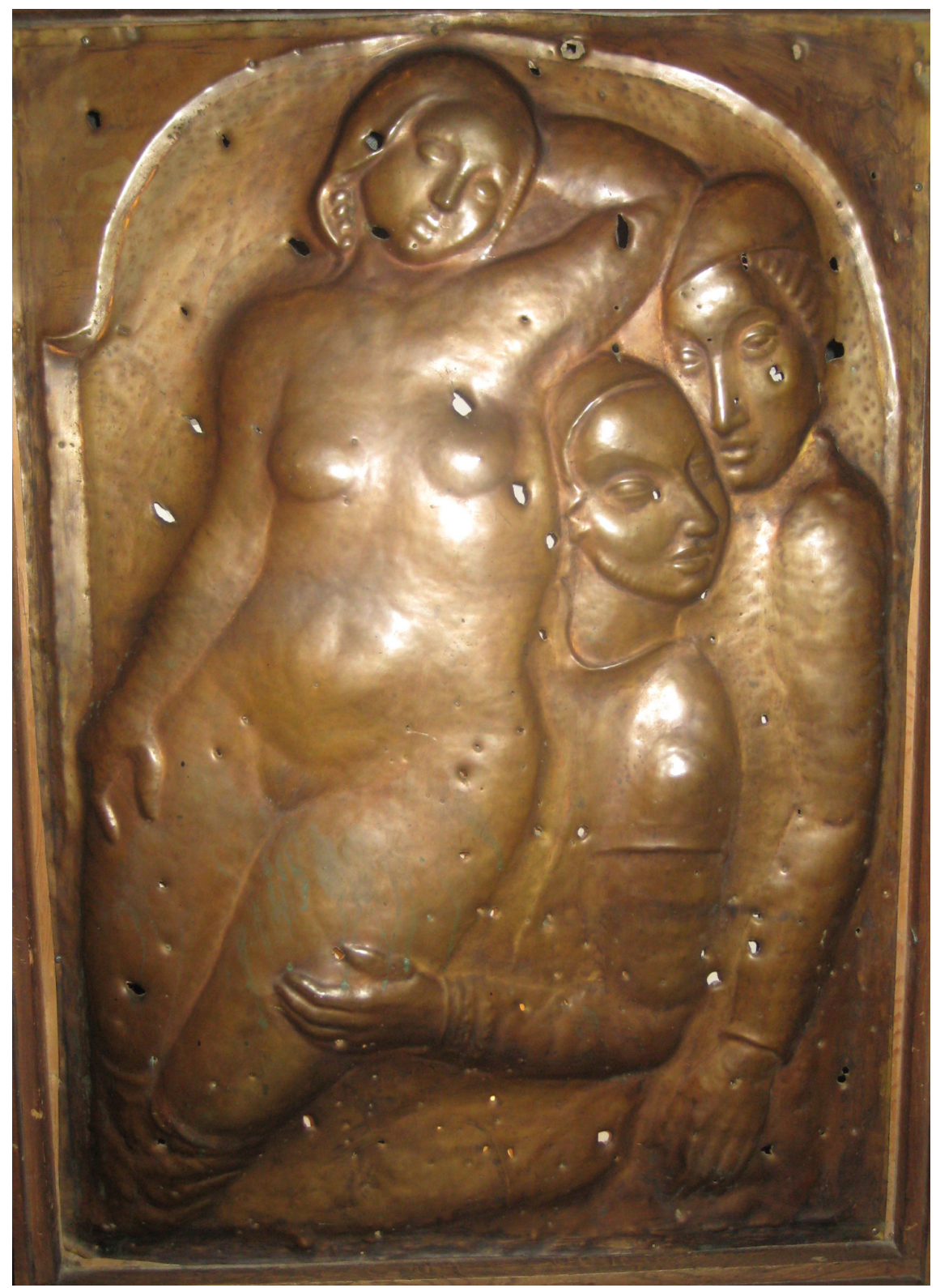

Fig. 8. Józef Śliwniak, Rahab and the spies, 1936, the metalwork collection of the Jewish Historical Institute in Warsaw (ŻIH). 
contacts, and connections between the different cultures and an intuitive feeling of a great threat and danger to come.

The motif of dialogue and contact between different people and communities is apparent in the copper relief Merzer made of Heine's "The Asra." It is an encounter by the fountain between the Sultan's daughter and a foreigner, a slave from the Asra tribe (see Fig. 9).

Daily the fair Sultan's daughter

Wanders to and fro at twilight

By the margin of the fountain,

Where the waters white are rippling.

Daily the young slave at twilight

Stands beside the fountain's margin,

Where the waters white are rippling,

Daily grows he pale and paler.

There one evening moved the princess

Toward the slave with words swift-spoken

"Tell me, tell me what thy name is,

Where thy home is, what thy lineage?"

Spake the youthful slave: "My name is

Mahomet, I come from Yemen;

And by birth I am an Asra,

One who dieth when he loves." ${ }^{\circ 3}$

Against the background of Heine's influence on Polish culture, this Oriental poem had also a contemporary relevance, as I have been trying to point out through my selection of images. ${ }^{54}$ The Asra people exemplified the essence of love and devotion, when they fell in love, it was a complete devotion that burned their physicality and focused on spiritual union "עזה כמוות אהבה" [for love is as strong as death]) also be read psychologically as representing relations of attraction and rejection against the background of fear and alienation. It is an impossible love-dangerous and unrealized forever.

${ }^{53}$ Heinrich Heine, "The Asra," in id., Poems and Ballads of Heinrich Heine, trans. Emma Lazarus (Portland, 2014), 117.

${ }^{54}$ On Heine's influences see Sol Lipzin, "Heine and the Yiddish Poets," in Mark H. Gelber (ed.), The Jewish Reception of Heinrich Heine (Tübingen, 1992), 67-75; Antony Polonsky, "Julian Tuwim, the Polish Heine," http://www.aapjstudies.org/index.php?id=115 [retrieved: 20 Apr. 2018].

${ }^{55}$ Songs of Solomon 8:6. 


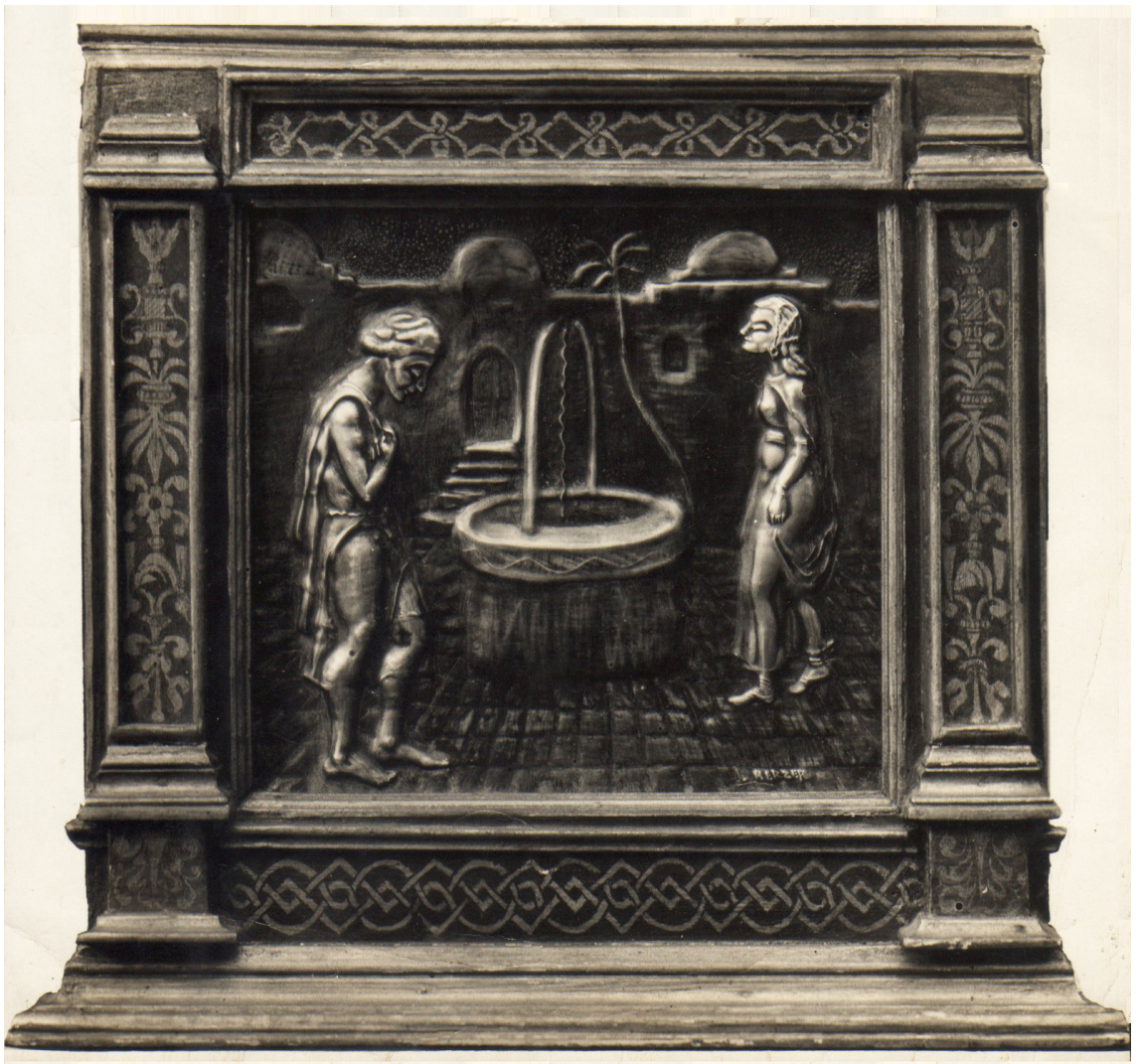

Fig. 9. Arieh Merzer, The Asra, copper relief, the early 1930s, MAC.

\section{Conclusion}

World War II devastated metaloplastics. Most of the copper sheets and reliefs disappeared under the rubble. The Nazis collected the Jewish metal items and moved some of them to Germany for documentation. They melted down most of them, turning them into weapons or other metal items. This led to the extinction of a body of Jewish art that was familiar in Poland, where almost every home had metal items, and wealthy homes frequently had collections of utilitarian, ritual, and artistic items, and later-often repoussé works. Metaloplastics nearly vanished. Among the works of Merzer, who was able to leave Poland at an early stage, a significant corpus of metaloplastic art was preserved and together with 


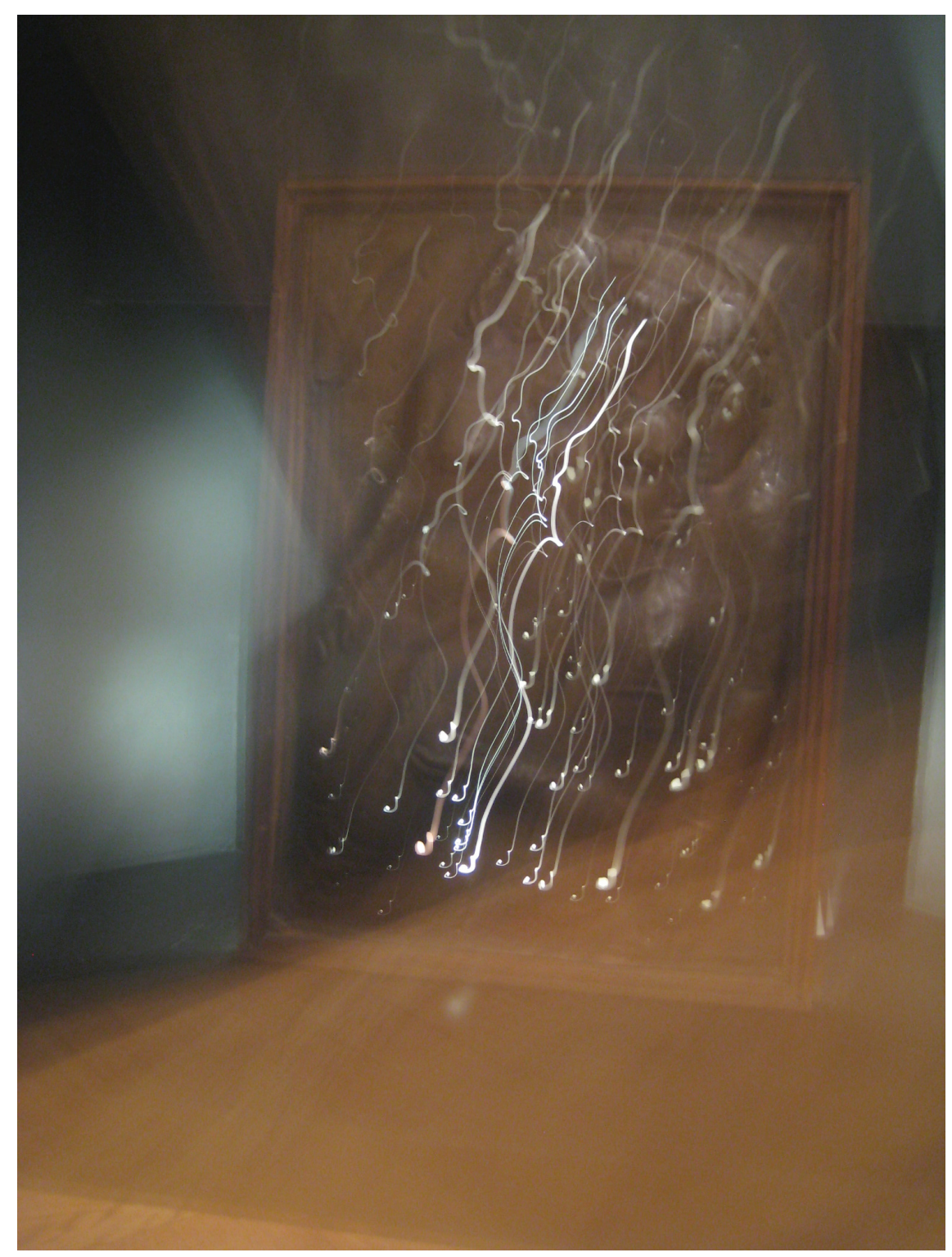

Fig. 10. Aviv Livnat, Reflections on the copper relief of Józef Śliwniak (Fig. 8), photo, 2008. 
few copper reliefs of the original Jewish Polish group they give a picture of the width and depth of this art. In my article I have attempted to trace some threads in the tapestry of metaloplastics. These threads which evolve from ancient Jewish traditions lead and are led to various times and places and reverberate in a modern Jewish euphony that is faithful to tradition and Jewish roots but open to the spirit of the times and its peoples. In the context of Polish culture and the art scene of the 1920s and 1930s, copper was also making its comment on the fragile and complicated contacts between Poles and Jews with its inner spiritual essence of unity and within its depths.

A magnificent relief of Śliwniak that was usually exhibited at the museum of the Jewish Historical Institute in Warsaw drew my attention for years. It was a work which Sandel had acquired for the Gallery of Jewish Art never revealing the circumstances under which the work had survived. I used to photograph it when I visited Warsaw while trying to trace the way light was conducted on its copper surface and through the holes. Those are holes possibly made during the war when the relief might have served as a shield in a bunker. The relief survived, depicting in my reading, the fragile Jewish-Polish liaison but also the natural light of our ongoing contemporary times which continue to shed light into and through it (see Fig. 10).

\section{Bibliography}

\section{Archival sources}

Livnat, Aviv, "Zikaron rakua be-nekhoshet: Sugiyot be-yetsirato shel ha-aman Arieh Merzer” (Ph.D. dissertation, Tel Aviv University, Tel Aviv, 2011).

\section{Primary sources}

Aronson, Chaim, "Hartske Goldshlak," Literarishe Bleter 122 (1926).

Merzer, Arieh, Biblical Images: Sixteen Copper Reliefs, intro. Itzik Manger (Safed, 1959).

Merzer, Arieh, Safed and Its People: Eighteen Reliefs in Metal (Safed, 1965).

Sandel, Józef, "Chaim Hanft," Yidishe Shriftn 5 (1961).

Shnayderman, Shmuel Leyb, "Arieh Merzer in Tsfat," Yidishe Kemfer (27 May 1966).

Szwarc, Marek, "Der natsyonaler element in der yidisher kunst," Literarishe Bleter 48 (1925). 


\section{Secondary sources}

Aronson, Chil, Bilder un geshtaltn fun Montparnass (Paris, 1963).

Bakhtin, Mikhail, Rabelais and His World, trans. Hélène Iswolsky (Bloomington, 1941).

Bartelik, Marek, Early Polish Modern Art: Unity in Multiplicity (Manchester, 2005).

Boné, Moshe, "Hebrew Inscriptions on Medieval Polish Coins," The Shekel 23 (1990), 2.

Cavanaugh, Jan, Out Looking in: Early Modern Polish Art, 1890-1918 (Berkeley, 2000).

Chrzanowska, Agnieszka, Metaloplastyka żydowska w Polsce (Warsaw, 2005).

Cohen, Nathan, Sefer sofer ve-iton, merkaz ha-tarbut ha-yehudit be-Varsha 1918-1942 (Jerusalem, 2002).

Dentith, Simon, Bakhtinian Thought: An Introductory Reader (London, 1995).

Goldstein, Maksymiljan, Dresdner, Karol, Kultura i sztuka ludu żydowskiego na ziemiach polskich (Lwów, 1935).

Grinboim, Yitskhok (ed.), Varsha: Encyclopedia shel Galuyot (Jerusalem, 19531973).

Grözinger, Elvira, Ruta, Magdalena (eds.), Under the Red Banner: Yiddish Culture in the Communist Countries in the Postwar Era (Wiesbaden, 2008).

Harshav, Benjamin, Manifestim shel modernism (Jerusalem, 2001).

Heine, Heinrich, Poems and Ballads of Heinrich Heine, trans. Emma Lazarus (Portland, 2014).

Henderson, Linda Dalrymple, The Fourth Dimension and Non-Euclidean Geometry in Modern Art (Princeton, 1983).

Heyd, Milly, "Lilien and Beardsley: 'To the Pure All Things Are Pure'," Journal of Jewish Art 7 (1980).

Jasieński, Bruno, Utwory poetyckie, manifesty, szkice, ed. Edward Balcerzan (Kraków, 1972).

Kantsedikas, Alexander, Bronze: Masterpieces of Jewish Art (Moscow, 1991).

Kurasiak, Małgorzata (ed.), Adam Rychtarski 1885-1957: Malarstwo (Lódź, 1981). Lipzin, Sol, "Heine and the Yiddish Poets," in Mark H. Gelber (ed.), The Jewish Reception of Heinrich Heine (Tübingen, 1992).

Livnat, Aviv, "Rikuey ha-nekhoshet shel Arieh Merzer: Zikhronot Yidish miTsfat," Motar 19-20 (2012).

Łoziński, Władysław, Złotnictwo lwowskie w dawnych wiekach, 1384-1640 (Lwów, 1889).

Malinowski, Jerzy, Grupa "Jung Idysz” i żydowskie środowisko "Nowej Sztuki” w Polsce 1918-1923 (Warsaw, 1987).

Malinowski, Jerzy, Malarstwo i rzeźba Żydów polskich w XIX i XX wieku (Warsaw, 2000).

Malinowski, Jerzy, Sztuka i nowa wspólnota: Zrzeszenie Artystów “Bunt” 1917-1922 (Wrocław, 1991).

Malinowski, Jerzy, Piątkowska, Renata, Stolarska-Fronia, Małgorzata, Sztyma, Tamara (eds.), Art in Jewish Society (Toruń, 2014). 
Malinowski, Jerzy, Piątkowska, Renata, Sztyma-Knasiecka, Tamara (eds.), Jewish Artists and Central-Eastern Europe: Art Centers, Identity, Heritage from the 19th Century to the Second World War (Warsaw, 2010).

Markus, Rut, Pisul be-kav uvechalal (Tel Aviv, 2003).

Peretz, Yitzhok Leibush, Mayselekh (New York, 1920).

Pollakówna, Joanna, Formiści (Wrocław, 1972).

Polonsky, Antony, “Julian Tuwim, the Polish Heine,” http:/www.aapjstudies.org/ index.php?id=115 [retrieved: 20 Apr. 2018].

Sandel, Józef, Plastishe kunst bay poylishe Yidn (Warsaw, 1964).

Sandel, Józef, Umgekumene yidishe kinstler (Warsaw, 1957).

Shatzky, Jacob, Geshikhte fun Yidn in Varshe (New York, 1953).

Stanisławski, Ryszard (ed.), Constructivism in Poland 1923-1936: Blok, Praesens, a.r. (Essen, 1973).

Steinberg, Shalom Dov, Tavnit ha-mishkan ve-keylav uvigdey ha-kodesh (Jerusalem, 1994).

Tibi, Nir, "Rahav ha-zona beyn megamot ba-mikra uvamidrash: Sipur bavua midrashi," Moresht Israel 12 (2015).

Torrès, Tereska, The Converts (London, 1970).

Turkow, Yonas, Hayo hayta Varsha ha-yehudit (Tel Aviv, 1969).

Ury, Scott, Barricades and Banners: The Revolution of 1905 and the Transformation of Warsaw Jewry (Stanford, 2012).

Vauxcelles, Louis, Marek Szwarc (Paris 1932).

Wiszniowska, Marta, "Popularity against the Odds: Ruskin and Zakopane," Acta Universitatis Nicolai Copernici: English Studies 5 (1995).

Zoref, Avraham, Moreshet ha-zorfut be-am Israel (Tel Aviv, 1983).

Aviv Livnat

Tel Aviv University

Bezalel Academy of Arts and Design

aviv@hagalil.com 